\title{
Morfološka karakterizacija sjemenki jagodastih voćnih vrsta
}

\author{
Morphological characterization of berry fruits seeds
}

\author{
Martina Skendrović Babojelić, Alma Zečević
}

\section{SAŽETAK}

Veličina i svojstva sjemenki jagodastih voćnih vrsta važan su parametar koji utječe na iskoristivost sjemenki odnosno produkciju pojedinih kemijskih komponenti prilikom njihova iskorištavanja kao nusprodukta prerade plodova. Sjemenke manjih dimenzija potrebno je opisivati s što više parametara, a danas je to moguće računalno razvijenim metodama. Cilj rada bio je utvrditi masu, opisati i analizirati sjemenke jagodastih voćnih vrsta (jagoda, malina, kupina, ribiz, borovnica, ogrozd i josta) pomoću WinSEEDLETM sustava, a na temelju morfometrijskih svojstava utvrditi razlike između pojedinih vrsta. Nakon provedenih istraživanja može se zaključiti da se jagodaste voćne vrste značajno razlikuju u izgledu kao i morfometrijskim svojstvima sjemenki. Najveća masa stotinu sjemenki utvrđena je kod bijelog ribiza, a najmanja kod šumske jagode i borovnice. Najveća projicirana površina te ravna duljina i ravna širina sjemenki utvrđena je kod bijelog ribiza, nešto manje vrijednosti utvrđene su kod kupine, a najmanje kod jagode. Analiza sjemenki pomoću novijih sofisticiranih metoda predstavlja značajan izvor podataka za dopunu istraživanja u vrednovanju vrsta i sorata. S obzirom da pojedine jagodaste voćne vrste sadrže dosta velik broj sjemenki koje uglavnom ostaju neiskorištene ili najčešće predstavljaju nusproizvod čak i otpad prilikom prerade plodova, rezultati ovakvih istraživanja mogu olakšati odabir pojedine vrste za određenu namjenu.

Ključne riječi: sjemenke, jagodaste voćne vrste, WinSEEDLE ${ }^{\mathrm{TM}}$ sustav, morfometrijska svojstva.

\section{ABSTRACT}

Size and characteristics of berry fruit seeds are important parameters which affect seed utility along with the production of certain chemical components during their processing as a by-product in fruit processing industry. For seeds of smaller size, it is necessary to describe as many parameters as possible which is now possible with specifically developed computer methods. The aim of the study was to determine seed weight and to analyse seeds of berry fruits (strawberry, raspberry, blackberry, currant, 
blueberry, gooseberry and jostaberry) with WinSEEDLETM system along with determining the differences between species and cultivars based on morphometric properties. One hundred seed weight was highest for white currant, and lowest for wild strawberry and blueberry. The greatest projected area together with straight length and straight width of the seed were observed in white currant while blackberry had slightly lower values and strawberry had the lowest. Significant differences between the mean values of the analysed morphometric parameters were determined within the genus Ribes and the examined blueberry cultivars, while the raspberry cultivars did not obtain significant differences for the majority of measured parameters. Seed analysis that uses modern and sophisticated methods represents a valuable source of data that could supplement research in evaluating species and cultivars. By identifying a greater number of seed characteristics it facilitates the selection of a particular species for a particular purpose meaning the size of fruits and seeds affects the profitability of certain technological processes and the utility of raw materials.

Key words: seeds, berry fruits, WinSEEDLE ${ }^{\mathrm{TM}}$ system, morphometric properties

\section{UVOD}

Dugogodišnjim selekcijskim radom stvorene su brojne vrste i sorte jagodastog voća. Neke od njih se intenzivno uzgajaju (jagoda, malina, kupina, ribiz), a one manje zastupljene imaju potencijal širenja (borovnica, ogrozd, josta). Različitosti u pogledu botaničke pripadnosti, morfoloških i pomoloških svojstava, te $\mathrm{u}$ konačnici njihova privredna važnost, upućuje na vrlo kompleksnu grupaciju određenih vrsti u skupini jagodastog voća (Kurtović i sur., 2016.). Općenito s obzirom na izgled i građu ploda pojedine vrste odnosno sorte unutar voćne vrste značajno se razlikuju (Ruiz i Egea, 2008.), a najočitije su razlike u boji, masi i dimenzijama ploda, broju, veličini i izgledu sjemenki (Höfer i sur., 2012.). Navedena svojstva moguće je utvrditi postupcima morfološke karakterizacije, a identifikacija sjemenki i određivanje njihovih morfoloških svojstava imaju važnu ulogu u klasifikaciji sorata. Ujedno oblik i veličina sjemenki otkrivaju određene genetske, fiziološke i ekološke komponente sorti koje direktno utječu na prirod, kvalitetu i samu tržišnu cijenu ploda (Cervantes i sur., 2016.). Iako se zbog povoljnog kemijskog sastava potiče konzumacija svježih plodova jagodastih voćnih vrsta, značajna je i njihova uporaba u proizvodnji soka, džema, marmelade, koncentrata soka, ali isto tako $\mathrm{i}$ iskorištavanje sjemenki kao nusproizvoda prerade čime je značajno proširen izbor proizvoda jagodastog voća (Micić, 2016). Sjemenke jagodastog voća imaju visoku nutritivnu vrijednost zbog sadržaja esencijalnih masnih 
kiselina (Parry i sur., 2006.), a udio ulja u sjemenkama pojedinih vrsta kreće se primjerice kod maline od 13,44 do 14,33\%, a kupine 13,97 do 14,34\% (Dimić i sur., 2012.). Obzirom na karakteristična pomološka i morfološka svojstva jagodastog voća, kao što su plodovi manje mase i dimenzija kao i sitne sjemenke (Nikolić i Milivojević, 2010.), morfološke analize plodova je potrebno opisivati sa što više parametara jer se često vrijednosti preklapaju (Wada i Reed, 2010.). Takve analize moguće je provoditi modernim tehnologijama, a podaci mjerenja mogu se dobiti isključivo računalno razvijenim metodama. Danas na raspolaganju postoji niz programskih podrški za ekstrakciju morfoloških podataka iz slike (Cobb i sur., 2013.). Jedan od novijih modela koji se svrstava u suvremenu tehnologiju je i WinSEEDLETM sustav koji služi za utvrđivanje morfoloških svojstava sjemenki. Tradicionalne metode za mjerenje morfometrijskih svojstava (pomična mjerila, ravnala) mogu odrediti samo jednostavne geometrijske parametre uzorka (duljina, širina i debljina), no, specifična svojstva, povezana sa sortom, često su u vezi $\mathrm{s}$ kompleksnijim parametrima. Računalno razvijenim metodama moguće je u kratko vrijeme izmjeriti više parametra vezanih za oblik analiziranog objekta ili pak regije na slici. Takav je primjerice i WinSEEDLETM sustav koji u vrlo kratko vrijeme može izmjeriti više od 10 parametara vezanih za oblik analiziranog objekta ili pak regije na slici. Sustav se temelji na analizi slike dobivene skeniranjem uzoraka sjemenki te pritom korisniku, u nekoliko puta kraćem vremenu, osigurava podatke o svojstvima veličine i oblika sjemenki značajne za njihovu morfološku karakterizaciju, a koji se ne mogu izmjeriti tradicionalnim načinom mjerenja. Utvrđivanjem većeg broja svojstva plodova i sjemenki pojedine voćne vrste doprinosi lakšem opisu i determinaciji vrste odnosno sorte, a isto tako olakšava odabir pojedine vrste za određenu namjenu budući da veličina plodova i sjemenki utječu na isplativost pojedinih tehnoloških procesa i iskoristivost sirovine (Hummer i Peacock, 1994.).

Cilj rada bio je utvrditi masu, opisati i analizirati sjemenke jagodastih voćnih vrsta (jagoda, malina, kupina, ribiz, borovnica, ogrozd i josta) pomoću WinSEEDLE ${ }^{\mathrm{TM}}$ sustava, a na temelju dobivenih rezultata utvrditi razlike $\mathrm{u}$ izgledu i morfometrijskim svojstvima između pojedinih vrsta. 


\section{MATERIJAL I METODE}

$\mathrm{U}$ istraživanje su bile uključene sjemenke sljedećih jagodastih voćnih vrsta: šumska jagoda (Fragaria vesca L.), vrtna jagoda (Fragaria $\times$ ananassa Duchesne), malina (Rubus idaeus L.), kupina (Rubus fruticosus L.), crveni ribiz (Ribes rubrum L.), crni ribiz (Ribes nigrum L.) i bijeli ribiz (Ribes album L.), borovnica (Vaccinium myrtillus L.), ogrozd (Ribes grossularia L.) i josta (Ribes nidigrolaria L.). Plodovi istraživanih vrsta ubrani su u optimalnom roku berbe $\mathrm{i}$ iz ubranih plodova pincetom su pažljivo izdvojene sjemenke koje su ispirane vodom i stavljene na sušenje u uvjete sobne temperature. Nakon sušenja izdvojene se zdrave i neoštećene sjemenke te su pospremljene u specijalne prozirne kutijice u kojima su čuvane do daljnjih analiza. Analiza sjemenki nakon sušenja temeljila se na utvrđivanju mase 100 sjemenki analitičkom vagom s četiri decimale (KERN ${ }^{\circledR}$ Analytical balance AES-C/AEJ-CM), a digitalna mjerenja morfometrijskih svojstava sjemenki, izvršena su pomoću optičkog skenera (Epson, STD 4800). Svojstava sjemenki analizirana su na principu slike pomoću WinSEEDLE ${ }^{\mathrm{TM}}$ sustava (Regent Instuments Inc. Canada). Sustav programske podrške izvršio je analizu sjemenki za sljedeća svojstva: projicirana površina sjemenke $\left(\mathrm{mm}^{2}\right)$, ravna duljina sjemenke $(\mathrm{mm})$, zakrivljena duljina sjemenke $(\mathrm{mm})$, ravna širina sjemenke $(\mathrm{mm})$, zakrivljena širina sjemenke $(\mathrm{mm})$, zakrivljenost sjemenke $(\mathrm{mm})$ i volumen sjemenke $\mathrm{s}$ kružnim presjekom modela $\left(\mathrm{mm}^{3}\right)$.

Statistička obrada podataka

Razlike između istraživanih vrsta statistički su analizirane analizom varijance (ANOVA), a tako utvrđene razlike između prosječnih vrijednosti testirane su LSD testom na razini signifikantnosti $p \leq 0,01$. Podaci su u cijelosti analizirani statističkim programom SAS 9.1.3. 


\section{REZULTATI I RASPRAVA}

Sjemenke jagodastih voćnih vrsta prikazana su na slici 1. Vrtna jagoda (1 A) i šumska jagoda (1 B) imaju izuzetno sitne sjemenke, čija je duljina tek nešto veća od $1 \mathrm{~mm}$ (Tablica 1). Morfološki se uočava kako su nepravilnog, bubrežastog oblika, glatke i sjajne, zlatno-žutog (vrtna jagoda) odnosno crvenkastog obojenja (šumska jagoda). Sjemenke borovnice (1 C) uglavnom su pravilnog ovalno-bubrežastog oblika, izrazito sitne, sjajne, zlatno-žutog do smeđeg obojenja. Zapažena su određena variranja u veličini i obliku sjemenki, koja mogu biti posljedica broja sjemenki po plodu što se poklapa sa istraživanjima Dalling (2002) koji navodi kako varijacije u veličini sjemenki mogu ovisiti od broja proizvedenih sjemenki po plodu kao i određenih ekoloških uvjeta uzgoja. Sjemenke kupine (1 D) i maline (1 E) bubrežastog su oblika, s većom ili manjom bočnom zakrivljenošću, a prepoznatljive su po mreži udubljenja koja prekriva njihovu površinu, što se ističe kao bitno morfološko svojstvo sjemenki ovih vrsta. Važno je napomenuti kako razlike u rubovima sjemenki mogu biti izuzetno korisne u prepoznavanju sorata. Wada i Reed (2010) izdvajaju 17 sorata kupine koje svrstavaju u tri identifikacijske kategorije prema obliku rubova sjemenke. Iako je jedna strana sjemenke najčešće polukružnog oblika, ističu kako druga može biti ravna, te manje ili više konkavna do manje ili više konveksna što se može uočiti i na slici 1 D. Sjemenke unutar roda Ribes $(1 \mathrm{~F}-1 \mathrm{H})$ su eliptične i jajolike, svijetlo do tamnosmeđeg obojenja. Unutar vrste sjemenke su relativno homogene u veličini i obliku, a najveće razlike se mogu uočiti na razini vrsta što se poklapa $\mathrm{s}$ istraživanjima Kendir i sur. (2015.), a vidljivo je i na slici 2 i tablici 1 prikazanih rezultata ovog istraživanja. Kod ogrozda (1 I) uočava se da su sjemenke eliptične i suzolike, šiljastog vrška, a na bazi tupe i oble. Golim okom površina sjemenki izgleda glatka, dok Wrońska-Pilarek (2002.) navodi kako je pod većim povećanjem površina sjemenki ipak retikularna odnosno mrežasta. Sjemenke joste $(1 \mathrm{~J})$ su izdužene, tanke, tamnosmeđeg obojenja, dosta neujednačenog oblika. Uočljiva je sličnost sjemenki joste i ogrozda posebno u boji i obliku, kao i u ostalim svojstvima prikazanim u rezultatima ovog istraživanja. 

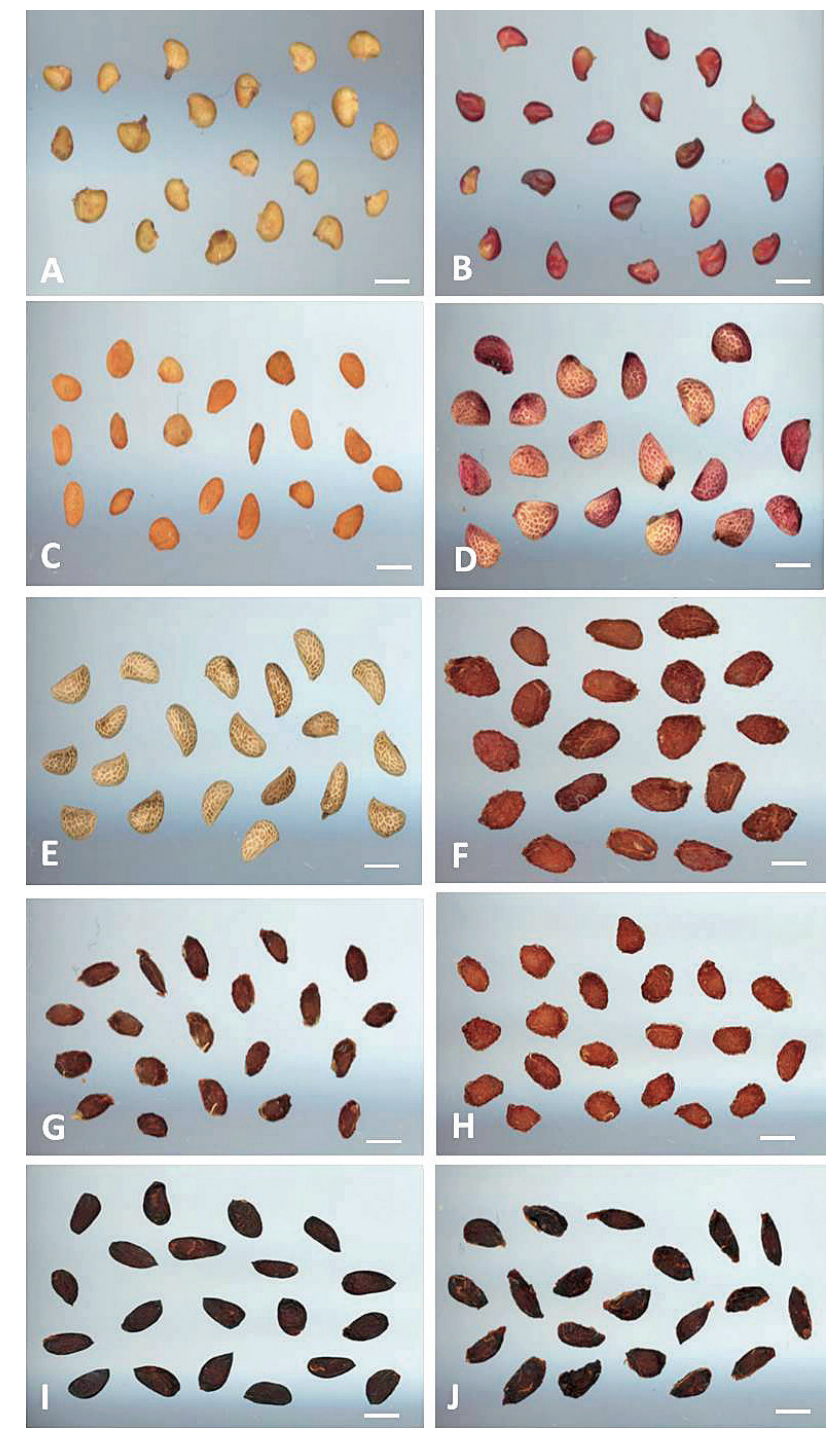

Slika 1. Sjemenke jagodastih voćnih vrsta: A - vrtna jagoda, B - šumska jagoda, C - borovnica, D - kupina, E - malina, F - bijeli ribiz, G - crni ribiz, H - crveni ribiz, I - ogrozd, J - josta. Skale = $1 \mathrm{~mm}$, A-C; Skale = 3mm, D-J.

Figure 1 Seeds of berry fruits: A - garden strawberry, B - wild strawberry, C - blueberry, D - blackberry, E - raspberry, F - white currant, H - red currant, I - gooseberry, J - jostaberry. Scale $=1 \mathrm{~mm}, \mathrm{~A}-\mathrm{C}$; Scale $=3 \mathrm{~mm}$, D-J 
Martina Skendrović Babojelić i sur.: Morfološka karakterizacija sjemenki jagodastih voćnih vrsta

Tablica 1. Osnovne dimenzije sjemenki istraživanih jagodastih voćnih vrsta utvrđene pomoću WinSEEDLE ${ }^{\text {TM }}$ sustava

Table 1 Basic dimensions of berry fruits seeds determined with WinSEEDLE'M system

\begin{tabular}{|c|c|c|c|c|c|c|c|c|}
\hline $\begin{array}{l}\text { VOĆNA } \\
\text { VRSTA }\end{array}$ & $\begin{array}{c}\text { Projicirana } \\
\text { površina } \\
\text { sjemenke } \\
\left(\mathrm{mm}^{2}\right)\end{array}$ & $\begin{array}{c}\text { Ravna duljina } \\
\text { sjemenke } \\
(\mathrm{mm})\end{array}$ & $\begin{array}{c}\text { Zakrivljena } \\
\text { duljina } \\
\text { sjemenke } \\
\text { (mm) }\end{array}$ & $\begin{array}{c}\text { Ravna širina } \\
\text { sjemenke } \\
(\mathrm{mm})\end{array}$ & $\begin{array}{c}\text { Zakrivljena } \\
\text { širina } \\
\text { sjemenke } \\
(\mathrm{mm})\end{array}$ & $\begin{array}{c}\text { Zakrivljenost } \\
\text { sjemenke }\end{array}$ & $\begin{array}{l}\text { Omjer širine } \\
\text { i duljine } \\
\text { sjemenke }\end{array}$ & $\begin{array}{c}\text { Volumen } \\
\text { sjemenke } \\
\text { s kružnim } \\
\text { presjekom } \\
\text { modela } \\
\left(\mathrm{mm}^{3}\right)\end{array}$ \\
\hline $\begin{array}{l}\text { ŠUMSKA } \\
\text { JAGODA }\end{array}$ & $0,72^{\mathrm{e}} \pm 0,13$ & $1,21^{\mathrm{c}} \pm 0,08$ & $1,26^{\mathrm{c}} \pm 0,10$ & $0,85^{\mathrm{b}} \pm 0,11$ & $0,85^{\mathrm{b}} \pm 0,13$ & $0,04^{\mathrm{a}} \pm 0,06$ & $0,70^{\mathrm{ab}} \pm 0,06$ & $0,39^{\mathrm{e}} \pm 0,12$ \\
\hline $\begin{array}{l}\text { VRTNA } \\
\text { JAGODA }\end{array}$ & $0,85^{\mathrm{e}} \pm 0,16$ & $1,21^{\mathrm{c}} \pm 0,11$ & $1,27^{\mathrm{c}} \pm 0,13$ & $0,98^{b} \pm 0,13$ & $0,98^{b} \pm 0,12$ & $0,04^{\mathrm{a}} \pm 0,05$ & $0,81^{\mathrm{a}} \pm 0,08$ & $0,56^{\mathrm{e}} \pm 0,17$ \\
\hline MALINA & $3,19^{b} \pm 0,40$ & $2,68^{\mathrm{ab}} \pm 0,14$ & $2,80^{\mathrm{ab}} \pm 0,14$ & $1,48^{\mathrm{ab}} \pm 0,16$ & $1,48^{\mathrm{ab}} \pm 0,16$ & $0,11^{\mathrm{a}} \pm 0,04$ & $0,55^{\mathrm{b}} \pm 0,06$ & $3,14^{\mathrm{c}} \pm 0,65$ \\
\hline KUPINA & $4,74^{\mathrm{ab}} \pm 0,64$ & $3,04^{\mathrm{ab}} \pm 0,21$ & $3,15^{\mathrm{ab}} \pm 0,23$ & $2,08^{\mathrm{a}} \pm 0,26$ & $2,07^{\mathrm{a}} \pm 0,26$ & $0,09^{\mathrm{a}} \pm 0,05$ & $0,68^{\mathrm{ab}} \pm 0,07$ & $6,34^{\mathrm{ab}} \pm 1,47$ \\
\hline BOROVNICA & $1,31^{\mathrm{d}} \pm 0,22$ & $1,60^{c} \pm 0,13$ & $1,64^{b c} \pm 0,14$ & $1,06^{b} \pm 0,15$ & $1,06^{b} \pm 0,15$ & $0,05^{b} \pm 0,04$ & $0,66^{\mathrm{ab}} \pm 0,10$ & $0,93^{\mathrm{e}} \pm 0,27$ \\
\hline $\begin{array}{l}\text { BIJELI } \\
\text { RIBIZ }\end{array}$ & $5,41^{\mathrm{a}} \pm 0,66$ & $3,34^{\mathrm{a}} \pm 0,22$ & $3,46^{\mathrm{a}} \pm 0,20$ & $2,18^{\mathrm{a}} \pm 0,28$ & $2,19^{\mathrm{a}} \pm 0,27$ & $0,07^{\mathrm{ab}} \pm 0,05$ & $0,66^{\mathrm{ab}} \pm 0,10$ & $7,77^{\mathrm{a}} \pm 1,73$ \\
\hline CRNI RIBIZ & $2,29^{\mathrm{c}} \pm 0,25$ & $2,36^{\mathrm{ab}} \pm 0,29$ & $2,41^{\mathrm{ab}} \pm 0,29$ & $1,33^{\mathrm{ab}} \pm 0,17$ & $1,32^{\mathrm{ab}} \pm 0,16$ & $0,04^{\mathrm{b}} \pm 0,04$ & $0,57^{\mathrm{ab}} \pm 0,11$ & $1,99^{\mathrm{d}} \pm 0,43$ \\
\hline $\begin{array}{l}\text { CRVENI } \\
\text { RIBIZ }\end{array}$ & $3,71^{\mathrm{b}} \pm 0,51$ & $2,72^{\mathrm{ab}} \pm 0,17$ & $2,77^{\mathrm{ab}} \pm 0,17$ & $1,83^{\mathrm{a}} \pm 0,23$ & $1,82^{\mathrm{a}} \pm 0,23$ & $0,04^{b} \pm 0,03$ & $0,67^{\mathrm{ab}} \pm 0,08$ & $4,44^{\mathrm{b}} \pm 1,06$ \\
\hline OGROZD & $5,21^{\mathrm{a}} \pm 0,56$ & $3,59^{\mathrm{a}} \pm 0,20$ & $3,64^{\mathrm{a}} \pm 0,19$ & $1,93^{\mathrm{a}} \pm 0,17$ & $1,93^{\mathrm{a}} \pm 0,17$ & $0,05^{\mathrm{b}} \pm 0,05$ & $0,54^{\mathrm{b}} \pm 0,05$ & $6,59^{\mathrm{ab}} \pm 1,20$ \\
\hline JOSTA & $4,95^{\mathrm{ab}} \pm 0,63$ & $3,89^{\mathrm{a}} \pm 0,34$ & $3,96^{\mathrm{a}} \pm 0,33$ & $1,75^{\mathrm{a}} \pm 0,21$ & $1,74^{\mathrm{a}} \pm 0,21$ & $0,05^{\mathrm{b}} \pm 0,04$ & $0,45^{\mathrm{c}} \pm 0,07$ & $5,56^{\mathrm{b}} \pm 1,36$ \\
\hline $\operatorname{Pr}>F$ & $\mathrm{P} \leq 0,0001$ & $\mathrm{P} \leq 0,0001$ & $\mathrm{P} \leq 0,0001$ & $\mathrm{P} \leq 0,0001$ & $\mathrm{P} \leq 0,0001$ & $\mathrm{P} \leq 0,0001$ & $\mathrm{P} \leq 0,0001$ & $\mathrm{P} \leq 0,0001$ \\
\hline
\end{tabular}

Napomena: Prikazane su prosječne vrijednosti \pm SD (standardna devijacija). Različita slova pridodana prosječnim vrijednostima označavaju da se sjemenke statistički značajno razlikuju u istraživanom svojstvu prema Fisher LSD testu uz $\mathrm{P} \leq 0,0001$.

Note: Presents the average values \pm SD (standard deviation). Data followed by different letters in the same column represents the seeds which have statistically significantly different characteristics according to Fisher's LSD test $(\mathrm{P} \leq 0,0001)$.

$\mathrm{Na}$ slici 2 prikazane su vrijednosti mase 100 sjemenki istraživanih jagodastih voćnih vrsta. Najmanja masa 100 sjemenki utvrđena je kod šumske jagode $(26,9 \mathrm{mg})$, vrtne jagode $(36,2 \mathrm{mg})$ i borovnice $(38,4 \mathrm{mg})$. Prema istraživanju Johansson i Kallio (1997.) masa 100 sjemenki šumske jagode iznosila je $30 \mathrm{mg}$, a masa borovnice $10 \mathrm{mg}$, dok Cerabolini i sur. (2003.) navode vrijednost mase 100 sjemenki jagode od $36 \mathrm{mg}$, a borovnice $35 \mathrm{mg}$. Vrijednosti mase 100 sjemenki jagode dobivene u ovom istraživanju poklapaju se istraživanjima navedenih autora, dok je kod borovnice u ovom istraživanju utvrđena veća masa sjemenki u odnosu na istraživanja navedenih autora. 
Pojedini autori navode kako ekološki čimbenici utječu na broj sjemenki u plodu, ali ne i na njihovu veličinu (McGinley, 1993.), dok s druge strane Dalling (2002.) tvrdi kako varijacije u veličini sjemenki mogu biti posljedica broja razvijenih sjemenki po plodu kao i određenih ekoloških uvjeta.

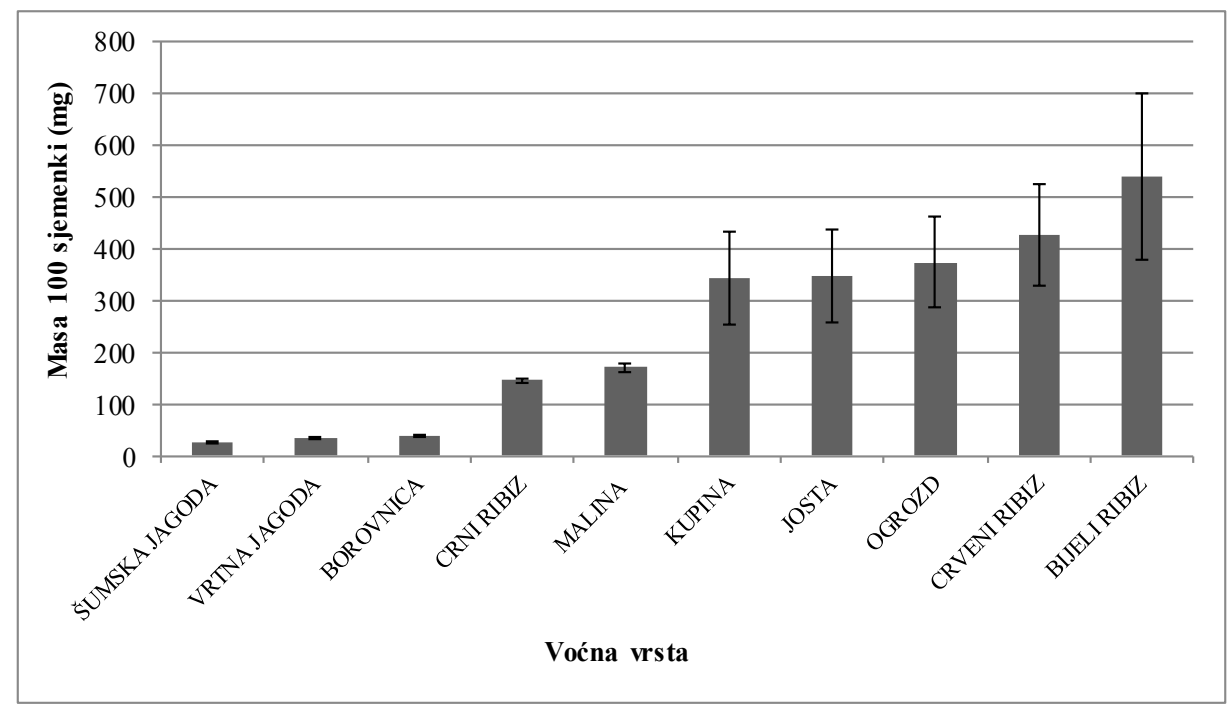

Slika 2. Prosječna masa sjemenki jagodastih voćnih vrsta

Figure 2 The average weight of the berry fruits seeds

Najveća masa 100 sjemenki utvrđena je kod bijelog ribiza (540,2 mg) koji je ujedno i imao najveću masu 100 sjemenki unutar roda Ribes, budući da je masa sjemenki crnog ribiza iznosila 145,3 mg, a crvenog ribiza 426,8 mg. U istraživanju Johansson i Kallio (1997) masa sjemenki unutar roda Ribes kretala se u rasponu od 90 do $360 \mathrm{mg}$, s tim da je masa crnog ribiza značajno manja $(90 \mathrm{mg}) \mathrm{u}$ usporedbi $\mathrm{s}$ rezultatima dobivenim u ovom istraživanju. Sjemenke su eliptične i jajolike, svijetlo do tamnosmeđeg obojenja. Kendir i sur. (2015.) navode da su sjemenke unutar roda Ribes relativno homogene $\mathrm{u}$ veličini i obliku, a najveće razlike se mogu primijetiti između vrsta što se poklapa i s rezultatima ovog istraživanja.

Masa 100 sjemenki maline iznosila je $170,7 \mathrm{mg}$ što je u skladu s istraživanjima Hummer i Peacock (1994.) koji su utvrdili da prosječna masa 100 sjemenki maline iznosi $170 \mathrm{mg}$, dok su Johansson i Kallio (1997.) utvrdili 
Martina Skendrović Babojelić i sur.: Morfološka karakterizacija sjemenki jagodastih voćnih vrsta

vrijednost mase 100 sjemenki maline od $180 \mathrm{mg}$ što je minimalno odstupanje u odnosu na rezultate ovih istraživanja. Masa 100 sjemenki kupine $(343,8 \mathrm{mg})$ iznosila je približno kao i masa sjemenki ogrozda $(373,8 \mathrm{mg})$ i joste $(348,3 \mathrm{mg})$. U ovom istraživanju utvrđene su sličnosti između sjemenki ogrozda i joste (međuvrsni hibrid crnog ribiza i europskog ogrozda), gdje su sjemenke joste više težile vrijednostima mase sjemenki ogrozda nego crnog ribiza, čime se može pretpostaviti kako je masa sjemenki svojstvo koje je kod joste jednim dijelom naslijeđeno od ogrozda, a ne od crnog ribiza koji ima manju masu sjemenki, iako na masu ploda i sjemenki osim genetskih čimbenika utječu i uvjeti uzgoja, agrotehnika, pomotehnika i drugi.

U istraživanju Sebesta i sur. (2013.) istraživana su morfološka svojstva sjemenki i plodova 22 sorte kupine te su se vrijednosti mase 100 sjemenki kretale između 270 i $400 \mathrm{mg}$ ovisno o sorti. Wada i sur. (2010.) na 17 istraživanih sorti utvrdili su da se masa 100 sjemenki kupine kretala od $80 \mathrm{mg}$ do najviše $430 \mathrm{mg}$. Dobiveni rezultati u ovom istraživanju za masu 100 sjemenki kupine $(343,8 \mathrm{mg})$ nalaze se u okviru rezultata istraživanja navedenih autora, odnosno masa sjemenki teži prema gornjoj granici dobivenih rezultata drugih autora te se može zaključiti da masa sjemenki značajno varira između većeg broja sorata.

U tablici 1 prikazane su prosječne vrijednosti istraživanih svojstava sjemenki jagodastih vrsta pomoću WinSEEDLE ${ }^{\mathrm{TM}}$ sustava: projicirana površina sjemenke, ravna duljina sjemenke, zakrivljena duljina sjemenke, ravna širina sjemenke, zakrivljena širina sjemenke, zakrivljenost sjemenke, omjer širine i duljine sjemenke i volumen sjemenke s kružnim presjekom modela. Između istraživanih svojstava utvrđene su statistički značajne razlike. Značajno najveće prosječne vrijednosti projicirane površine utvrđene su kod bijelog ribiza $\left(5,41 \mathrm{~mm}^{2}\right)$ i ogrozda $\left(5,21 \mathrm{~mm}^{2}\right)$. Sjemenke maline i crvenog ribiza su imala približno istu površinu koja se značajno razlikovala u odnosu na prethodno navedene vrste kao i u odnosu na sjemenke borovnice i jagode kod kojih je utvrđena značajno najmanja projicirana površina sjemenki. Značajno najveća ravna i zakrivljena duljina sjemenki utvrđena je kod bijelog ribiza, ogrozda i joste, a najmanja kod šumske jagode i vrtne jagode koje se međusobno nisu razlikovale u vrijednostima istraživanih svojstava. Vrijednosti ravne duljine kretale su se između 1,21 mm kod šumske jagode i 3,89 mm kod joste, a zakrivljene duljine od 1,26 mm kod šumske jagode do 3,96 kod joste. Za svojstvo zakrivljenosti sjemenke najviše vrijednosti utvrđene su kod analiziranih sjemenki maline $(0,11)$ i kupine $(0,09)$ u odnosu na ostale istraživane vrste jagodastog voća. Navedeno svojstvo kao i većina ostalih 
svojstva osnovnih dimenzija sjemenki (Tablica 1) nisu se značajno razlikovali unutar ove dvije vrste te je time i kroz detaljnu analizu dokazana i već vidljiva sličnost sjemenki maline i kupine. Uz najveću masu 100 sjemenki (Slika 2), kod bijelog ribiza utvrđene su i najveće vrijednosti volumena sjemenke s kružnim presjekom modela $\left(7,77 \mathrm{~mm}^{3}\right)$. Najniže vrijednosti utvrđene su kod sjemenki borovnice $\left(0,93 \mathrm{~mm}^{3}\right)$ te vrtne jagode $\left(0,56 \mathrm{~mm}^{3}\right)$ i šumske jagode $\left(0,39 \mathrm{~mm}^{3}\right)$.

Iako su sjemenke jagodastih voćnih vrsta vrlo malih dimenzija razlike u pojedinim svojstvima su uočljive i mjerljive zahvaljujući upravo novijim tehnologijama što je prikazano i u ovom istraživanju. Antunović (2018.) je istraživao utjecaj folijarnog gnojiva "Silitec" na svojstva ploda i sjemenki jagode sorte 'Malwina'. U navedenom istraživanju također je primijenjen WinSEEDLETM sustav te nisu utvrđene značajne razlike istraživanih morfoloških svojstava unutar različitih tretmana. Na sjemenkama čiji plodovi nisu tretirani gnojivom (kontrola) utvrđene su sljedeće vrijednosti: projicirana površina sjemenke $-1,28 \mathrm{~mm}^{2}$, ravna duljina sjemenke $-1,53 \mathrm{~mm}$, zakrivljena duljina sjemenke - 1,72 mm, ravna širina sjemenke - $1,23 \mathrm{~mm}$, zakrivljena širina sjemenke - 1,27 mm, zakrivljenosti sjemenke - 0,09 te volumen sjemenke sa kružnim presjekom modela $-1,14 \mathrm{~mm}^{3}$. Navedene vrijednosti su značajno veće $\mathrm{u}$ odnosu na dobivene rezultate dimenzija sjemenki šumske $\mathrm{i}$ vrtne jagode $\mathrm{u}$ ovom istraživanju, što može biti posljedica sorte, sustava uzgoja, vremena uzimanja uzoraka i drugih čimbenika.

Prema istraživanju Wada i sur. (2010.) srednja vrijednost duljine sjemenki 17 sorata kupine iznosila je $3,56 \mathrm{~mm}$ dok je najniža utvrđena vrijednost iznosila $2,49 \mathrm{~mm}$, a najviša $4,30 \mathrm{~mm}$. Prosječna vrijednost širine sjemenki iznosila je $2,16 \mathrm{~mm}$. Navedene vrijednosti poklapaju se s rezultatima ovih istraživanja gdje je duljina sjemenke iznosila $3,04 \mathrm{~mm}$, a širina $2,08 \mathrm{~mm}$. Wrońska-Pilarek (2002.) je provela istraživanja morfoloških svojstava raličitih vrsta roda Ribes, i utvrdila je duljinu sjemenki ogrozda između $2,5-2,8 \mathrm{~mm}$, a širinu između $1,2-1,5 \mathrm{~mm}$. Navede vrijednosti su značajno niže u odnosu na rezulate ovih istraživanja gdje je duljina sjemenki ogrozda iznosila $3,59 \mathrm{~mm}$, a širina $1,93 \mathrm{~mm}$. Ista autorica navodi vrijednosti duljine sjemenke crnog ribiza od 1,7 do $2,0 \mathrm{~mm}$, a širine od 1,0 do $1,2 \mathrm{~mm}$, koje su nešto manje u odnosu na dobivene rezultate u ovom istraživanju gdje je utvrđen duljina sjemenke crnog ribiza iznosila $2,36 \mathrm{~mm}$ a širina $1,33 \mathrm{~mm}$. Vrijednosti duljine sjemenke crvenog ribiza iznosile su $2,72 \mathrm{~mm}$, a širine $1,83 \mathrm{~mm}$ što je u skladu $\mathrm{s}$ istraživanjima Wrońska-Pilarek (2002.) gdje je utvrđena duljina između 2,2 i 2,8 mm te širina od 1,5 do $2,0 \mathrm{~mm}$. Slična odstupnja rezultata za iste vrste utvrđena su u istraživanjima Kendir sur. (2015.) gdje je vrijednost duljine sjemenki ogrozda 
iznosila $3 \mathrm{~mm}$, a širina $1,7 \mathrm{~mm}$, za crni ribiz duljina sjemenke iznosila je $2 \mathrm{~mm}$, a širina $1,05 \mathrm{~mm}$, a duljine sjemenke za crveni ribiz iznosila $2,3 \mathrm{~mm}$, a širina $1,5 \mathrm{~mm}$. Odstupanja od dobivenih vrijednosti mogu biti posljedica različitih svojstava genotipa, broja sjemenki u plodu, ekoloških uvjeta uzgoja pojedinih vrsta, a vrlo slične zaključke iznose i McGinley (1993) i Dalling (2002) u svojim istraživanjima.

\section{ZAKLJUČAK}

Nakon provedenih istraživanja može se zaključiti da se jagodaste voćne vrste značajno razlikuju u izgledu kao i morfomterijskim svojstvima sjemenki. Analiza sjemenki pomoću novijih sofisticiranih metoda predstavlja značajan izvor podataka za dopunu istraživanja u vrednovanju vrsta i sorata. S obzirom da pojedine jagodaste voćne vrste sadrže dosta velik broj sjemenki koje uglavnom ostaju neiskorištene ili najčešće predstavljaju nusproizvod pa čak i otpad prilikom prerade plodova, rezultati ovakvih istraživanja mogu olakšati odabir pojedine vrste za određenu namjenu. Voćne vrste čije sjemenke su većih dimenzija se mogu puno bolje iskoristiti kao sirovina, primjerice za ekstrakciju ulja koje zauzima sve veći značaj.

Daljnja istraživanja trebalo bi usmjeriti na utvrđivanja količine sjemenki po vrstama odnosno razlike između sorata unutar vrsta kako bi mogle izdvojiti potencijalne vrste i sorte za razvoj daljnjih tehnologija proizvodnje ulja iz sjemenki. Budući da sve brojnija istraživanja ukazuju na vrijednost ovog sirovog materijala i povećavaju zainteresiranost potrošača za proizvodima od sjemenki različitih voćnih vrsta, svojstva sjemenki voćnih vrsta mogu ukazati na isplativost pojedinih tehnoloških procesa $\mathrm{i}$ iskoristivost sirovine.

\section{LITERATURA}

ANTUNOVIĆ, A. (2018.): Uzgojne mjere kod sorte jagoda 'Malwina' u zaštićenom prostoru (Diplomski rad). Sveučilište u Zagrebu, Agronomski fakultet, str. 27.

CERABOLINI, B., CERIANI, R. M., CACCIANIGA, M., DE ANDREIS, R., RAIMONDI, B. (2003.): Seed size, shape and persistence in soil: a test on Italian flora from Alps to Mediterranean coasts. Seed Science Research. 13.1: $75-85$. 
CERVANTES, E., MARTÍN, J. J., SAADAOUI, E. (2016.): Updated methods for seed shape analysis. Scientifica. 2016: 1-10.

COBB J. N., DECLERCK G., GREENBERG A., CLARK R., MCCOUCH, S. (2013.): Next-generation phenotyping: requirements and strategies for enhancing our understanding of genotype-phenotype relationships and its relevance to crop improvement. Theoretical and Applied Genetics. 126.4: 867-887.

DALLING, J. (2002.): Ecología de semillas. pp. In: Guariguata, M. and G. Kattan (eds.). Ecología y conservación de bosques neotropicales. Editorial Tecnológica de Costa Rica, Puerto Rico.

DIMIĆ, E., VUJASINOVIĆ, V., RADOČAJ, O., PASTOR, O. (2012.): Karakteristike semena i ulja kupine i maline. Acta periodica technologica. 43: $1-9$.

HÖFER, M., FLACHOWSKY, H., HANKE, M. V., SEMËNOV, V., ŠLÂVAS, A., BANDURKO, I., SOROKIN, A., ALEXANIAN, S. (2012.): Assessment of phenotypic variation of Malus orientalis in the North Caucasus region. Genetic Resource in Crop Evolution. 60.4: 1463-1477.

HUMMER, K. E., PEACOCK, D. N. (1994.): Seed Dimension and Weight of Selected Rubus Species. HortScience. 29.9: 1034-1036.

JOHANSSON, A., KALLIO, H. (1997.): Characterization of seed oils of wild, edible Finnish berries. Zeitschrift für Lebensmitteluntersuchung undForschung A. 204.4: 300-307.

KENDIR, G., GÜVENÇ, A., ACAR, A., ÇETER, T., PINAR, N. (2015.): Fruits, seeds and pollen morphology of Turkish Ribes L. (Grossulariaceae). Plant Systematics and Evolution. 301.1: 185-199.

KURTOVIĆ, M., GAŠI, F., GRAHIĆ, J., MALIČEVIĆ, A., OKIĆ, A., GRBO, L. (2016.): Jagodasto voće - biologija, tehnologija uzgoja, rasadnička proizvodnja i oplemenjivanje. Sarajevo: Grafičar promet, Sarajevo.

MCGINLEY, M. (1993.): Variation in reproductive characteristics of Poa pratensis across a succesional chronosequence. Texas Journal of Science. 45: 105-108. 
MICIĆ, D. M. (2016.): Hemijska i termalna analiza semena jagodastog voća. (Doctoral dissertation) Univerzitet u Beogradu - Fakultet za fizičku hemiju.

NIKOLIĆ, M. D., MILIVOJEVIĆ, J. M. (2015.): Jagodaste voćke. Tehnologija gajenja. Beograd: Univerzitet u Beogradu, Poljoprivredni fakultet.

PARRY, J., SU, L., MOORE, J., CHENG, Z., LUTHER, M., RAO, J. N., YU, L. L. (2006.): Chemical compositions, antioxidant capacities, and antiproliferative activities of selected fruit seed flours. Journal of Agricultural and Food Chemistry. 54.11: 3773-3778.

Regent Instruments Inc. - Image Analysis for Plant Science (2018.): WinSEEDLE ${ }^{\mathrm{TM}}$. http://regent.qc.ca/assets/winseedle_about.html. Pristupljeno 03.05.2019.

RUIZ D., EGEA J. (2008.): Phenotypic diversity and relationships of fruit quality traits in apricot (Prunus armeniaca L.) germplasm. Euphytica. 163: 143-158

SEBESTA, B., CLARK, J. R., Threlfall, R. T., Howard, L. R. (2013.): Characterization of seediness attributes of blackberry genotypes. Discovery, The Student Journal of Dale Bumpers College of Agricultural, Food and Life SCIENCES. 14.1: 72-79.

WADA, S., REED, M. B. (2010.): Seed coat morphology differentiates blackberry cultivars. Journal of the American Pomological Society. 64.3: 151-160.

WROŃSKA-PILAREK, D. (2002.): Seed morphology of the native species of the genus Ribes L. Part 2. The characteristics of individual species. Acta Societatis Botanicorum Poloniae. 71.1: 5-16.

Adresa autora - Author's address:

Prof. dr. sc. Martina Skendrović Babojelić, e-mail: mskendrovic@agr.hr

Alma Zečević, studentica, diplomski studij Hortikultura

Sveučilište u Zagrebu Agronomski fakultet, Svetošimunska cesta 25, 10000 Zagreb, Hrvatska 
